\title{
Research on the Integrated Teaching Model of Open Education and Vocational Education
}

\section{-Taking the "Two-School Integration" Open University for Example}

\author{
Jiamin Huang \\ Research Office, Zhejiang Open University, Hangzhou, China \\ Email: 317663861@qq.com
}

How to cite this paper: Huang, J.M. (2021) Research on the Integrated Teaching Model of Open Education and Vocational Education. Open Access Library Journal, 8: e8111. https://doi.org/10.4236/oalib.1108111

Received: August 23, 2021

Accepted: November 9, 2021

Published: November 12, 2021

Copyright $\odot 2021$ by author(s) and Open Access Library Inc.

This work is licensed under the Creative Commons Attribution International License (CC BY 4.0).

http://creativecommons.org/licenses/by/4.0/

\begin{abstract}
At present, open education and vocational education are in the stage of mutual integration. In the process of building a lifelong learning system, many Open Universities in China operate open education and vocational education in the mode of "integrating two schools". These Open Universities with the "two-school integration" mode are a new way to transform and develop in the "communication" and "connection", and to promote the integrated operation of open education and vocational education with the integrated pedagogy theory. It is found that insufficient theoretical knowledge of the two types of education, low willingness to integrate and there are still "two skins" phenomenon, teachers and students of the two types of education have no intersection and isolated work content, and the potential of the integration of academic education and non-academic education is a real dilemma that hinders the transformation and development of Open University. Open University needs to build and share in the integration of specialty and curriculum, promoting the deep integration of open education and vocational education based on community theory, and turn the governance ability to: first, it needs to reshape the quality view and realize the lifelong education value guidance of Open University; second, we should promote the deep integration of open education and vocational education based on community theory; third, build an open learning resource sharing platform and promote the transformation and development of Open University, in order to plastic the quality concept of lifelong education together to realize the value guidance of open education and vocational education; finally, share the advantages of Open University and integrate the professional curriculum system for open education and vocational education. To promote the integrated development of the two types of education based on the community not only reflects the open and lifelong education concept of Open University, but also has the relatively perfect prac-
\end{abstract}


tice and theory of Open University in China and abroad, which is a great significance and value to the transformation and development of Open University.

\section{Subject Areas}

Distance and Open Education and Vocational Education

\section{Keywords}

Open Education, Vocational Education, Integrated Construction, Teaching Model

\section{Introduction}

At present, open education and vocational education are in the stage of mutual integration. In recent years, the state has promulgated and implemented a series of programmatic documents to closely combine the development of open education with the development of higher education and vocational education. For example, the Fourth Plenary Session of the 19th CPC Central Committee proposed "improve the coordinated development of vocational and technical education, higher education, continuing education"; China Education Modernization 2035 (2018-2022) clearly requires a modern education system serving lifelong learning and academic education, to promote the integration of non-academic education, vocational education and post-vocational education with online learning and offline learning; and the Opinions of the Ministry of Education "update the organic combination of higher education, vocational education, continuing education and distance open education" [1].

With the development of the era of "Internet+" and the education reform of online teaching under the normalization of epidemic prevention and control, vocational education is also actively promoting the overall integration of online learning. The trend of open education towards professionalism and vocational education will be more obvious, and the integration of the two types of education will be closer. In the process of building the lifelong learning system, many domestic Open Universities run open education and vocational education in the "one-school integration" mode of "one set of schools and two brands". Of the 44 provincial Open Universities in China, 27 have full-time ordinary secondary and higher vocational and technical colleges. Open Universities with the "two-school integration" mode are a new way to transform and develop in the "communication" and "connection", and to promote the integrated operation of open education and vocational education with the integrated pedagogy theory.

However, open education and vocational education have different educational modes, teaching characteristics and historical background, there are also theoretical and practical dilemmas; it seems very difficult to achieve full integration in the short term. For example: the theoretical cognition of the two types of 
education is not enough and the value recognition is not high, resulting in weak willingness to integrate. There is still the phenomenon of independent "two styles" independently, teachers and students of the two types of education have no intersection, and the work content is even more isolated from each other. The mutual integration of teaching means and learning methods is not enough, just like vocational education focuses on practical training but lacks online teaching, open education focuses on online learning but lacks practice. The integrated information platform environment integrating the two types of education needs to be further constructed.

According to these dilemmas have all hampered the deep integration of the two classes of education. Open University should take the teaching mode reform as the starting point, with a community of a shared future, teachers and a cultural community, from the level of building a new learning mode adapted to "Internet+", promoting the integration of professional curriculum construction, training the quality of "double teachers" teachers, and build an "overpass" for lifelong learning of credit banks. We should promote the integration of learning resources and professional courses, exploring the construction of a deeper open education and vocational education community. To realize the destiny sharing and teaching integration and cultural identity in the true sense, so we will promote the deep integration and equal benefits of open education and vocational education.

\section{The Professional Construction Status of the Open University in China}

\subsection{The Relationship between the Two Types of Education Integration}

During the reach of open education and vocational education, academic and practical educators have several viewpoints like "complementation", "fusion", "symbiosis". Many scholars believe that the integration of the two types of education is still in the shallow stage of "grafting" integration, but from the development trend of Open University, Song Pu, Shen Xiaofang (2018) believe that the relationship between the two types of education needs from the traditional "central" theory to "symbiosis", and point out that the two symbiosis development should take equality and reciprocity, talent training as the core and legal guarantee need to establish a scientific and reasonable quality guarantee system [2].

\subsection{Major Construction of " $1+5$ " Open University in China}

The professional setting of typical open universities such as Open University of the UK, University of Phoenix, and Japan Delivery University is relatively complete, both including academic education and non-academic education. Such as British Open University, Japan release university education level including bachelor's, master and doctor's. 
Since 2012, China Radio and Television University and Radio and Television University in Beijing, Shanghai, Jiangsu, Guangdong, Yunnan (" $1+5$ ” Open University) and other provinces have been renamed "Open University" and explored the pilot project of "Open University Construction Model”. However, open university level is relatively low in China, even with Chinese characteristics of " $1+5$ " Open University, also only opened a bachelor's degree and junior college education. From the practice of holding the two types of education development, the more rational and practical view is to realize the coordinated promotion and sustainable development of the two types of education. Wu Nanzhong (2015) studied the integration representation and timing of open education and vocational education) [3], believing that the symbol of integration is the integration of learning resources, curriculum integration, professional integration, management system integration and cultural integration, and pointed out that the integration must follow a certain timing.

Although Open University in various countries is different in major and curriculum, their goals are the same, which are to provide a more flexible and convenient learning platform for adults. From the perspective of professional construction positioning, local pilot Open University try to set up characteristic majors, in line with the local economic and social development. For example, in order to meet the major strategic needs of Guangdong's economic and social development, Guangdong Open University focuses on the construction of standardized engineering major, which is the only university in Guangdong Province with the establishment right and degree awarding right of this major.

As the perspective of professional construction, the leading role of National Open University is still a great demonstration role, and from the perspective of professional building capacity, the professional construction capacity of the pilot open universities is still weak. In terms of the existing school system, except for the " $1+5$ " pilot Open University, the other 39 provincial open universities do not have the autonomy in professional construction, but are under the unified responsibility of the National Open University.

Therefore, we should pay attention to the construction and development of China Open University, and deeply integrate open education and vocational education, and give play to the leading role of Open University in the transformation and development of Open University system, and build Open University with more discourse power and greater influence in the international Open University system.

\section{The Practical Difficulties Facing the Major and Curriculum Construction of Open Education and Vocational Education in China}

\subsection{The Integration of Open Education and Vocational Education Is Not Enough}

However, open education and vocational education have different educational 
modes, teaching characteristics and historical background, It seems very difficult to achieve full integration in the short term, There are also both theoretical and practical dilemmas, For example: the theoretical cognition of the two types of education is not enough, the value recognition is not high, resulting in weak willingness to integrate; There is still the phenomenon of independent "two skins" independently, Teachers and students of the two types of education have no intersection, Work content is even more isolated from each other; The mutual integration of teaching means and learning methods is not enough; Vocational education focuses on practical training but lacks online teaching, Open education focuses on online learning but lacks practice; The integrated information platform environment integrating the two types of education needs to be further constructed. These dilemmas have all hampered the deep integration of the two classes of education.

\subsection{The Teaching Integration and Integrated Development Mode Is Not Strong}

At present, among the 16 domestic Open University, only 5 Open University and vocational education are managed by the same academic affairs department, such as Guangdong, Jiangsu, Yunnan, Chongqing and Liaoning, which can explore "integration" in the two types of education. Most of the other Open University carry out two types of education work by independently setting up academic offices or secondary colleges and departments, resulting in the separation of open education and vocational education, and their independent governance, such as Hunan, Hubei, Henan, Jiangxi, Guizhou and other Open University. Open education is integrated into a department of vocational colleges, and open education is marginalized, such as Ningxia Open University and Ningxia Vocational and Technical College. This shows that the current reality of the integrated development of Open University and vocational colleges is not ideal, and the effect of the integrated development is not obvious.

\subsection{Professional and Curriculum System Construction Has Not Yet Formed a Unified Paradigm between Open Education and Vocational Education}

Under the reality of limited autonomy in professional construction, the curriculum system, curriculum requirements and assessment standards of Open University have been copied from ordinary university [4], Open University courses and ordinary courses is not obvious, professional and curriculum system did not form a unity. The synchronization and integration of open education and vocational education at the level of professional construction are insufficient, especially the construction of professional core courses, practical courses of open education are relatively weak. Due to the late start of student practice curriculum projects and the lack of "double-teacher" teachers in open education, the ability to guide students to carry out curriculum learning and practice is insufficient, which is not consistent with the requirements of adult higher education profes- 
sionalism.

\subsection{The Supporting Effect of the Curriculum Setting on the Professional Construction Is Weak in Open University}

Vocational education focuses on practical training and lack of online teaching, open education focuses on online learning but insufficient practice; the integrated information platform environment of the two types of education needs to be further constructed [5]. At present, the curriculum setting of Open University can't support the requirements of professional construction. The curriculum construction of open education does not have a thorough understanding of the construction content, while the curriculum construction of vocational education lacks openness, and the integrated scheme of online learning.

\section{Path and Countermeasures for the Integration of Open Education and Vocational Education}

\subsection{Promoting the Deep Integration of Open Education and Vocational Education Based on Community Theory}

The research group introduced the community theory proposed by German sociologist Tennes, to provide solid theoretical support for the integration of the two types of education. Open University of the "two schools", the top-level design can't be broken in the short term, taking the teaching mode reform as the starting point with a community of a shared future and a cultural community. From the level of building a new learning mode adapted to "Internet+", promoting the integration of professional curriculum construction, training the quality of "double teachers" teachers, and build an "overpass" for lifelong learning of credit banks. We will promote the integration of learning resources, professional courses, and cultural integration in an orderly manner. Exploring the construction of a deeper open education and vocational education community, to realize the destiny sharing and teaching integration and cultural identity, so we will promote the deep integration and equal benefits of the two types of education.

\subsection{Building an Open Learning Resource Sharing Platform and Promote the Transformation and Development of Open University}

With the established open education and continuing education learning platform, and with the help of massive resources such as MOOC, to create an integrated resource sharing platform, to make selection, integration and transformation are adopted [6], so that all resources can be used for open education and vocational education at the same time. To build a new type of open universities, it is necessary to closely follow the requirements of the National Comprehensive Reform Plan of Open University, strengthen the governance of Open University. Although open education and vocational education have different philosophy and training goals, so have mode and quality standards, we should still need to 
further establish a unified diversified quality, especially on quality improvement to great effort, open education needs to strengthen students' basic quality education. Become adult first and then become talented, and vocational education focuses more on the training of skilled talents, as well as strengthen skills training and vocational ability.

\subsection{Plasticing the Quality Concept of Lifelong Education Together to Realize the Value Guidance of Open Education and Vocational Education}

The dual mode of "two schools in one" universities is not a unique phenomenon of open universities. The international mode of open education and vocational education is becoming integrated. British Open University is a world famous university for vocational and technical education; American community college is a model of higher vocational and distance education; there are 39 universities with national qualification, including 14 for integrated distance education; Singapore universities better combine traditional face-to-face teaching and open education model to form a "mixed learning model" and ideal choice for University of Singapore.

In different stages of economic and social development, due to the different priorities of education and the different directions of talent training, open universities are bound to have different positioning and tasks. In the development of higher education from elite education to popularization, the function and positioning of open university became stable. Nowadays, it is a new mission and responsibility in the new era of Open University to build a nationwide lifelong learning system and a new university to support the national lifelong education system. To the first-class new institutions of higher learning, open university need to establish a unified diversified quality, urgently need to establish a lifelong education concept, establish in line with the local characteristics of open university philosophy, training goals, school mode and quality standards, from integration to lead economic and social development, especially on the quality improvement, different from the characteristics and characteristics of ordinary institutions of higher learning, build a number of superior disciplines, brand professional and quality courses. The connotation of the quality view should reflect the difference of open university, especially the current electric university collective renamed to open university, need to let people accept the new university name, form a high consensus among teachers, students, and widely recognized by the government, society and employers and peers, this is a long-term construction process, need to open university constantly reflection and promotion in the process of running.

\subsection{Sharing the Advantages of Open University, Integrating the Professional Curriculum System for Open Education and Vocational Education}

We will promote the joint construction and sharing of professional courses. First, 
promote the consistency of two types of education in professional construction with a professional system centered on improving the professional ability of learners; the second, realize curriculum construction and sharing, based on the requirements of online learning in the "Internet+" era, realize the compatible of curriculum content and presentation mode, maintain the sharing of paper textbooks and network resources, weaken the difference of the two types of education curriculum systems, and realize the integration of curriculum resources.

In addition, to build a new learning mode to adapt to the "Internet+". As the center of learner transformation, we should strengthen the cultivation of learners' independent learning ability and creative learning ability, not only innovating new online and offline learning models, but also promoting the integration of open education and vocational education. For example, SPOC teaching mode can be introduced into two types of education to solve the problems such as low attendance of face-to-face teaching courses, low proportion of students' active learning online resources, and difficulty in engineering training and teaching.

It's a constant struggle to build a credit bank lifelong learning "overpass". Building an "overpass" with open recognition of education and vocational education credits with the core of course selection and exchange of learning results, to realize the mutual recognition of learning achievements of post-vocational education and post-vocational education, therefore we can make academic education and non-academic education connected, and establish lifelong learning files for learners.

\subsection{Increasing the Faculty Team Building of Open University, Cultivating the Quality of "Double Teachers"}

The key to whether the two types of education are "integrated" is whether to cultivate teachers who not only adapt to online education and learning support services, but also have rich practical skills. Only by organizing effective online or offline classroom teaching is we by strengthening the training of teachers and giving teachers with the dominant power in classroom, curriculum construction and professional transformation. Under the perspective of the modernization of lifelong education governance, Open University should be committed to fully meeting the diversified learning needs of students, and promote the transformation and development from vocational education to academic education and non-academic education. Therefore, the open university professional and curriculum to fully study students personalized, not only to academic education and to fully develop non-academic education, but also to provide convenient and massive learning resources.

In open education, Open University should mainly implement the open education of National Open University and realize the integration of teaching and management, develop majors and courses that suit local needs and serve local development [7]. In vocational education, Open University should pay attention to the lifelong education system research, constantly explore cooperation with different countries and different enterprises and different industries, to streng- 
then the connection and integration with vocational education, and give full play to the synergistic effect and scale benefits of Open University.

\section{Summary and Prospect}

The integration of open education and vocational education is not a simple additive relationship, but the teaching mode reform design based on the idea of "integration and integration", we should not only require deeper theoretical research, but also play the initiative to practice and solve the related problems of integrated development in a level and orderly manner. Taking the opportunity of the Comprehensive Reform of the National Open University, local Open University should explore new ideas and new practices for coordinated development with National Open University, to promote the integration of open education and vocational education. With the deepening of the integration of open education and vocational education, how to better promote the integration, realize the advantageous interaction between the two types of education and share the interests of education are the key issues to Open University with the "two schools" mode. We should study and solve these problems, and contribute to the social construction of high-level Open University and lifelong learning.

\section{Found Project}

This paper is the research result of Zhejiang Educational Science 2021 Planning Project "Research on the Integration of Open Education and Vocational Education under the Perspective of the Community-Taking the "Two-School Integration' Open University for Example" (Project No: 2021SCG244).

This paper is also the research result of Zhejiang Radio and Television University 2020 Higher Education and Teaching Reform Project "Research on the Path of Integrated Major and Curriculum Construction of Open University under the Modernization Vision Of Education Governance" (Project No: XJG202014).

\section{Conflicts of Interest}

The author declares no conflicts of interest.

\section{References}

[1] Department of Vocational Education and Adult Education of the Ministry of Education (2020, No.6) Notice of the Ministry of Education on the Issuance of the Comprehensive Reform Plan of the National Open University. http://www.moe.gov.cn/srcsite/A07/zcs zhgg/202009/t20200907 486014.html

[2] Song, P. and Shen, X.F. (2018) The Current Situation, Dilemma and Governance Outlet of Distance Education and Vocational Education. Adult Education, No. 1, 18-22.

[3] Wu, N.Z. (2015) Characterization, Timing and Realization Path of the Integration of Distance Open Education and Vocational Education. Continuing Education Research, No. 6, 45.

[4] Xu, H.F., Wei, A.H. and Li, X.H. (2017) Five Years of Open University: Summary and Reflection-Review of "Seminar on Progress and Achievements in the Con- 
struction of Open University". Open Education Research, No. 6, 21-25.

[5] Yang, H.Y. (2020) Analysis of the Feasibility and Realization Ways of the Deep Integration of Open Education and Higher Vocational Education. Journal of Guizhou Radio and Television University, No. 3, 10-15.

[6] Liu, J.X. (2017) The Mode and Path of Integrating Distance Education and Vocational Education under the Background of "Internet+". Continuing Education Research, No. 11, 9-11.

[7] Liu, W.X. (2017) Problems and Paths of the Integration of Distance Education and Vocational Education. Education and Occupation, No. 9, 111. 